\author{
Marin Beroš \\ Institut društvenih znanosti »Ivo Pilar«, Područni centar Pula, Leharova 1, HR-52100 Pula \\ mberos@pilar.hr
}

\title{
Kozmopolitika kao preduvjet globalne pravednosti
}

\section{Sažetak}

Živote koje ćemo voditi ne određuju samo naša tijela, nego i okolina u kojima će se ta tijela nalaziti. Sama činjenica da rođenje osoba istih tjelesnih i mentalnih sposobnosti na različitim mjestima na Zemlji dovodi do potpuno drukčijih životnih prilika trebala bi nas zabrinjavati. I dok se puka tjelesnost ne može i ne bi smjela jednačiti kako bi se postigla pravednost u prilikama koje pojedinci imaju u društvu, odnosi unutar i među političkim zajednicama se mogu i moraju mijenjati ako želimo pravedniji svijet. Kozmopolitika kao grana političke filozofije, kroz prožimanje ideja kozmopolitizma i demokracije, bavi se razmatranjima kako je te je li uopće moguće stvoriti istovremeno pravedan i učinkovit globalni politički sustav. Ovaj rad će pružiti pregled osnovnih problema vezanih uz uspostavu kozmopolitske demokracije, te će na samom kraju biti razmotreni i neki konkretniji prijedlozi za uspostavu kozmopolitske demokracije teoretičara kao što su David Held i Daniele Archibugi.
\end{abstract}

\section{Ključne riječi}

kozmopolitika, kozmopolitizam, globalna pravednost, globalno upravljanje, kozmopolitska demokracija

\section{Kozmopolitska ideja i kozmopolitika}

$»$ Ni med cvetjem ni pravice«, tvrdi naslov jedne od najpoznatijih pjesama iz Krležine zbirke Balade Petrice Kerempuha. Ako je to uistinu točno, zašto je ljudima kroz povijest bilo toliko stalo do uspostave pravednog svijeta? Pravednost je tema koja i filozofiju prati od samih početaka - kao značajno pitanje prepoznata je u Platona i Aristotela, dok u novije vrijeme tema dobiva novi život s radom Johna Rawlsa. U svom kapitalnom djelu Teorija pravednosti, Rawls na samom početku otkriva zašto nam je toliko stalo do pravednosti:

$»$ Pravednost je prva vrlina društvenih institucija [...].«

A zatim nastavlja:

»... zakoni i institucije, koliko god bili učinkoviti ili dobro uređeni, moraju biti promijenjeni ili ukinuti ako su nepravedni. «1

Dakle, bez neke koncepcije pravednosti, društveni (a posljedično i politički) život ljudi bio bi nezamisliv.

Ipak, treba odmah na početku reći da globalna pravednost, o kojoj će također biti riječi u ovom radu, ne figurira kao značajna u Rawlsovu razmišljanju.

1

John Rawls, A Theory of Justice. Revised Edition, Belknap Press, Cambridge, MA 1999. str. 3 . 
Njegov je fokus prvenstveno na teritorijalno omeđenoj političkoj zajednici, odnosno na državama kako ih shvaćamo danas. Takav, prema njegovim kritičarima uski pogled zahtijevao je odgovor, a mogli bismo reći da se iz tog njihovog odgovora razvila sasvim nova znanstvena disciplina unutar političke filozofije koja se bavi pitanjima globalne pravednosti. Na početku 21. stoljeća, globalna pravednost sve više prestaje biti »samo《 akademska disciplina i polako prerasta u društveni pokret koji pokušava utjecati na aktualne centre političke moći da bi se omogućio ravnopravniji razvoj svih ljudi na svijetu; inicijativama za otpis duga zemljama u razvoju, nuđenjem raznih oblika humanitarne pomoći te općenito brigom za razvoj institucija koje će omogućiti sve veće sudjelovanje pojedinaca u političkom životu zajednice. Ovo je projekt koji ima svoj izvor u onome što bismo mogli nazvati »Zapadom« našeg svijeta, ali je (barem u dobrom dijelu) prihvaćen i u ostatku svijeta.

Globalna se pravednost uistinu čini kao dobra ideja, ali kako do nje doći? Ovaj će rad pokušati pokazati da je za njenu uspostavu najbolji način ideja kozmopolitizma, odnosno s njom usko povezan kozmopolitički projekt, projekt upravljanja svijetom putem globalnih demokratskih institucija nastalih kroz korištenje globalnih demokratskih procedura. Da bismo razjasnili što je kozmopolitika i što sve ona uključuje, trebamo se vratiti na same početke ideje kozmopolitizma. Ona je u filozofskom promišljanju prisutna već više od dvije tisuće godina i svoje postojanje duguje kiničaru Diogenu iz Sinope. Diogen je sebe prvi proglasio kozmopolitom, ali ne samo da bi iskazao svoju prisnost s cijelim svijetom nego da bi označio svoje neslaganje sa zakonima antičkih grčkih polisa. Iako je možda Diogenu namjera bila politička, kozmopolitska se ideja prvenstveno razvijala kao etički koncept, za što su ponajprije »krivci« stoici. Premda u kasnoj stoi dolazi do pokušaja jednačenja etičkog koncepta kozmopolisa s Rimskim Carstvom (prvenstveno u djelima Cicerona), kozmopolitska ideja značajno utječe na politiku tek u našem vremenu globalizacije. Sam preokret, koji je ovaj etički kozmopolitizam preobrazio $\mathrm{u}$ politički, stigao je nešto ranije $\mathrm{s}$ Immanuelom Kantom, za kojega bismo mogli reći da je predstavljao ne samo prekretnicu u dotadašnjem kozmopolitskom promišljanju nego je i jasno naznačio problem s kojim se i danas kozmopolitizam suočava:

»Najveći problem za ljudsku vrstu, na čije rješenje priroda nagoni čovjeka, jest uspostava građanskog društva kojim će se upravljati prema općem pravu. «²

Kantovu težnju za uspostavom »građanskog društva upravljanog prema općem pravu«, odnosno kozmopolitskog društva ustrojenog prema onome što on naziva kozmopolitskim pravom, potiče uvjerenje da tek s kultivacijom našeg globalnog okruženja mogu i pojedinci postići ispunjenje svih svojih prirodnih potencijala. Čak i ako izbacimo moralnost iz naše prosudbe i pristupimo ovom problemu čisto utilitaristički, zastrašujuće je i pomisliti koliko čovječanstvo svake godine gubi samo zato što više od dvije milijarde ljudi živi $\mathrm{u} »$ nesretnijim « mjestima zemaljske kugle i osnovna briga im nije znanost, umjetnost ili dobrobit drugih, nego puka tjelesnost, odnosno preživljavanje na granici siromaštva i gladi.

Ovaj nam problem nužno postavlja pitanje: kad bismo svi uistinu prigrlili kozmopolitska načela u našem životu, te kad bi granice dosadašnjih država izgubile svoj značaj za našu moralnu prosudbu, kakvu bismo tada političku zajednicu izgradili i na kakvim bi pravilima ona bila zasnovana? Također, mogli bismo se zapitati postoji li, zahvaljujući sve većoj globalizaciji, te s njom povezanoj kozmopolitizaciji društva, ikakva osnova za uspostavu 
kozmopolitske političke zajednice? Sve veće opadanje značaja nacionalnih država i smanjivanje njihove moći suverenog odlučivanja čine ovo pitanje politički sve važnijim. Je li moguće prenijeti građanska prava s nacionalne na nadnacionalnu zajednicu (poput Europske unije) te posljedično na cijelu kozmopolitsku zajednicu? Hoće li ta politička zajednica biti liberalna i demokratska ili će možda biti totalitaristička diktatura? Veliki broj autora koji se bave pitanjima globalnog upravljanja smatraju da su upravo demokratska načela i institucije najpogodnije za globalnu vladavinu, a na osnovi tih razmišljanja zasnovano je polje političke filozofije pod imenom kozmopolitika.

Pitanje kozmopolitike, odnosno globalne vladavine demokratskog oblika, dobiva sve veći znanstveni interes u posljednjih dvadeset godina, koji se pojavljuje paralelno s jačanjem globalizacijske teorije, kao i uz obnovljeni interes za ideju kozmopolitizma općenito. Kako su nam globalizacijski procesi zorno pokazali, globalni problemi poput prirodnih katastrofa, bolesti i gladi, pa sve do onih nastalih ljudskim djelovanjem, poput ratova, terorizma, ali i financijskih kriza, uistinu zahtijevaju i globalnu razinu njihova rješavanja. Zbog tog je razloga vanjska politika, odnosno polje međunarodnih odnosa, sve manje pod isključivom nadležnošću nacionalnih država. Sve više nenacionalnih, odnosno nadnacionalnih organizacija postaje značajan akter u ovoj areni. $\mathrm{Na}$ ovaj način, suverene moći država su narušene, što pak posljedično potkopava demokratske kapacitete nacionalnih vlada. Stoga niz autora, među kojima su svakako najistaknutiji David Held i Daniele Archibugi, zagovaraju proširenje demokracije na globalnu razinu kao jedini način na koji bi se takvi problemi upravljanja mogli legitimno riješiti. Daniele Archibugi tako tvrdi da politički projekt kozmopolitske demokracije može biti izražen vrlo jednostavno kao:

»... pokušaj da se pomiri fenomen globalizacije s uspjehom demokracije. On kreće od priznavanja činjenice da je demokracija zasnovana na državama, jedini oblik koji poznajemo danas, u opasnosti izgubiti značaj u procesima globalizacije. U isto vrijeme, dinamika globalizacije treba biti regulirana, a provoditi to isključivo na razini država teško je, a ponekad i nemoguće. ${ }^{3}$

Također, Archibugi tvrdi da je bitno svojstvo kozmopolitske demokracije pretpostavka da demokracija unutar država ne vodi nužno do globalne demokracije. Kao što je vidljivo iz političkog razvoja svijeta, povećanje broja zemalja koje prihvaćaju demokratski oblik upravljanja ne vodi izravno do globalne demokracije, odnosno potrebna je odluka upravo tih istih demokratskih država da polje međunarodnih odnosa prestanu shvaćati prema modelu prikrivenog rata svih protiv svih te da prihvate načela i vlast demokracije na međunarodnoj razini. Demokracija je postigla stvarne uspjehe unutar država, ali postojanje više njih zajedno niti čini odnose među njima manje hobsijanskima, niti rješavanje globalnih pitanja lakšima.

Stoga Archibugi zaključuje da su važni globalni ciljevi, poput kontrole ili uporabe sile, poštivanja ljudskih prava te samoodređenja, dohvatljivi samo kroz produžetak i produbljivanje demokracije. Ovaj pristup se razlikuje od uobičajenog kozmopolitskog pristupa ne samo prema tome što poziva na globalnu odgovornost nego i prema tome što se načela demokracije stvarno pokušavaju primijeniti međunarodno. Zapravo, problemi kao što su zaštita okoliša, regulacija migracija ili korištenje prirodnih resursa toliko su značajni za cijelo svjetsko stanovništvo da se nužno moraju podvrći nekom obliku globalne demokratske kontrole.

2

Immanuel Kant, »Ideja opće povijesti s gledišta svjetskog građanstva«, u: Pravno-politički spisi, Politička kultura, Zagreb 2000., str. 23.
3

Daniele Archibugi, »Demos and Cosmopolis«, u: Daniele Archibugi (ur.), Debating Cosmopolitics, Verso, London 2003., str. 261. 
Archibugi, usprkos pozivu na oblikovanje kozmopolitskih demokratskih institucija, također tvrdi da sama kozmopolitska demokracija ne zahtijeva rastakanje postojećih država da bi se stvorila svjetska država. Za obavljanje određenih političkih i administrativnih funkcija najpogodnije su upravo države, a ni problemi s kojima se države suočavaju neće se jednostavno riješiti ako stvorimo jednu univerzalnu državu. Iz tog razloga, proširenje demokracije s državne na globalnu razinu zahtijeva potpuno novi oblik organizacije, a ne puko obnavljanje državnog modela na svjetskoj razini ili pak »kozmetičko« preoblikovanje već postojećih međunarodnih institucija. Archibugi tvrdi da ono što razlikuje kozmopolitsku demokraciju od drugih projekata globalne vladavine jest, prije svega, pokušaj stvaranja institucija koje bi omogućile pojedincima da se i njihov glas čuje, neovisno o njegovoj snazi unutar vlastite zajednice. Stoga, slijedeći Kanta, Archibugi zaključuje da demokraciju treba realizirati na tri različite, ali međusobno povezane razine - unutar država, između država, ali i na svjetskoj razini.

David Held, također, nalazi da dosadašnja politička teorija više ne može odgovoriti na zahtjeve koje pred nju postavlja suvremeni umreženi svijet. U eseju »Democracy: From City States to Cosmopolitan Order« svoje razmatranje započinje s konstatacijom kako se čini da je demokracija odnijela pobjedu nad drugim oblicima vladavine. ${ }^{4}$ Njeno širenje svijetom intenziviralo se u posljednjih četvrt stoljeća. Padom Berlinskog zida, demokracija se 1990-ih proširila istokom Europe, sve do srednje Azije, u zemlje koje ove oblike vladavine nikad prije nisu ni poznavale. Ne tako davno, bili smo svjedoci Arapskog proljeća koje je transformiralo zemlje sjeverne Afrike i prijetilo isto počiniti različitim oblicima diktatura, monarhija i teokracija Bliskog istoka. Usprkos ovom slavodobitnom pobjedničkom krugu demokracije po svijetu, Held upozorava da je ova sveprisutnost demokracije u stvari novina jer je sve do dvadesetog stoljeća bilo jako malo primjera demokratske vladavine i oni su uglavnom bili ograničene na manje političke formacije. Razlog tome je svakako to što je demokraciju teško održati. Ona je izuzetno zahtjevan oblik vladavine, čija se učinkovitost smanjuje što je više sudionika u nju uključeno. Iz tog se razloga, iz direktnih oblika demokracije koji su postojali u antičkom dobu, u modernom dobu razvila predstavnička demokracija koja, iako povećane učinkovitosti, nosi sa sobom cijeli niz novih problema od kojih je pitanje legitimnosti samo jedan, ali ujedno i najvažniji.

Iako bismo Immanuela Kanta teško mogli nazvati zagovornikom demokracije s obzirom na to da pod tim pojmom smatra oblik antičke neposredne demokracije kakav je nespojiv s republikanskim oblikom vlasti koji smatra najboljim, njegova ideja kozmopolitskog prava nadahnula je zagovornike kozmopolitske demokracije, među njima ponajviše Helda, na razvijanje kozmopolitskog demokratskog prava. Nadovezujući se na svoj rad o teoriji demokracije u »Modelima demokracije«, te zabrinut zbog sve većeg nedostatka legitimnosti međunarodnih organizacija kao što su Ujedinjeni narodi, Held se u Democracy and the Global Order: From the Modern State to Cosmopolitan Governance naslanja na Kantova politička promišljanja da bi razvio ideju kozmopolitske demokracije. ${ }^{5}$ Held započinje s premisom da bi pravno-politički sustav trebao osigurati autonomiju pojedincu, odnosno mogućnost da on koristi svoj razum samosvjesno te da bude autor vlastita života. Ovo pak zahtijeva postojanje demokratskog javnog prava koje bi reguliralo institucije i osiguravalo prava pojedincima. Kako autonomija pojedinca može biti ugrožena događajima nastalim izvan njegove države, demokratsko javno pravo mora biti prošireno izvan okvira države razvojem kozmopolitskog demokratskog prava. 
Ipak, odnos između Heldova i Kantova kozmopolitskog prava ide dublje od pukog izbora riječi. Prema Heldu, Kantova ograničenija ideja kozmopolitskog prava kao načela opće gostoljubivosti ne samo da osuđuje kolonijalizam, ona ima implikacije koje podupiru njegov koncept kozmopolitskog demokratskog prava, i to iz razloga što opća gostoljubivost mora uključivati i uživanje autonomije kao i poštovanje nužnih ograničenja autonomije, odnosno uzajamno priznavanje i poštivanje jednakih prava drugih ljudi. U našem superpovezanom svijetu drugi, čija prava moramo priznati, nisu samo oni nama bliski nego svi oni s čijim smo sudbinama povezani bilo putem ekonomije ili putem okoliša ili putem politike. Stoga, Held tvrdi, opća gostoljubivost nije postignuta ako se pitanja o nečijem životu vode bez njihove mogućnosti sudjelovanja, slaganja i pristanka. Iz ovog argumenta Held zaključuje:

»Uvjet opće gostoljubivosti, ili, kako bih to radije naveo, kozmopolitske orijentacije, jest kozmopolitsko javno pravo. $\ll^{6}$

Nadalje, Held tvrdi da s razvojem kozmopolitske demokracije:

»Načela individualnih demokratskih država i društava mogla bi se poklopiti s onima kozmopolitskog demokratskog prava. Posljedično, prava i odgovornosti ljudi u svojstvu nacionalnih građana i ljudi u svojstvu subjekata kozmopolitskog prava mogla bi se poklopiti, a demokratsko građanstvo bi moglo preuzeti, u načelu, uistinu univerzalni status. U tim okolnostima, moglo bi se reći usvajajući Kanta, pojedinci koji čine države i društva čiji su ustavi oblikovani u skladu s kozmopolitskim pravom mogli bi se smatrati građanima ne samo njihovih nacionalnih zajednica ili regija nego i univerzalnog sustava 'kozmo-političke' vladavine. $\aleph^{7}$

Usko povezana s pitanjima prava uvijek su i pitanja pravednosti, stoga je s pitanjem kozmopolitskog prava povezano i pitanje globalne pravednosti. Unutar opće teme globalne pravednosti možemo prepoznati više struja, koje možemo podijeliti ovisno o njihovu interesu za pitanja raspona pravednosti, pitanja distributivne pravednosti i pitanja institucija odgovornih za provedbu pravednosti. Od te tri struje, suvremena politička filozofija pokazuje najviše interesa za pitanja globalne distributivne pravednosti. Heater $\mathrm{u} »$ World Citizenship« identificira četiri osnovna argumenta vezana uz globalnu distributivnu pravednost. ${ }^{8}$ Prvi argument tvrdi da se svjetsko društvo ubrzano razvija prema oblicima koji nalikuju onima unutar države te da, analoški, ako distributivna pravednost vrijedi na razini države, prema istom kriteriju trebala bi vrijediti i na globalnoj razini. Drugi argument, oslonjen na prvu tvrdnju, obrazlaže da se moralna odgovornost privilegiranih, naime da dijele svoje privilegije s onim neprivilegiranima, ne može ograničiti s granicama teritorijalne države. Treći argument tvrdi da su neprivilegirani često osuđeni na takvo stanje zbog geografskih prilika, odnosno grubost klime i siromaštvo prirodnih bogatstava često su čimbenici koji određuju životne prilike pojedinaca. Stoga bismo se trebali zapitati o pravu država, u prirodno povoljnijem položaju, da same eksploatiraju te arbitrarno locirane resurse Planeta. Četvrtim argumentom, koji

David Held, » Democracy: From City-States To Cosmopolitan Order«, Political Studies, god. 40 (1992), sv. 1, suppl., str. 10-39, doi: http://dx.doi.org/10.1111/j.1467-9248.1992. tb01810.x.

5

David Held, Democracy and the Global Order: From the Modern State to Cosmopolitan Governance, Stanford University Press, Stanford, CA 1995.
6

Ibid., str. 228-229.

Ibid., str. 233-234.

8

Derek Heater, World Citizenship. Cosmopolitan Thinking and its Opponents, Bloomsburg Publishing, Continuum, New York 2002., str. 115-116. 
vrijedi i za globalne i za unutardržavne uvjete, ističe se da siromaštvo ide u paru s nedostatkom moći, zbog čega osiromašeni žele političku moć da bi ispravili distribucijske nejednakosti. Heater tvrdi da se ova četiri argumenta mogu izvesti iz različitih početnih pozicija; kako iz deontoloških - svi pojedinci posjeduju ljudska prava; sva ljudska bića su moralno jednaka te stoga imaju pravo na razuman standard življenja - tako i iz utilitarističkih - redistribucija resursa proširila bi razinu sreće i potaknula veću sklonost miru u svijetu. Usprkos različitim početnim pozicijama, ciljevi su im kozmopolitski u svim slučajevima.

Ipak, pozivi na globalnu distribuciju dobara na osnovi kozmopolitske ideje imaju i svoje kritičare. Osnovni, a ujedno i najjači argument protiv ideje globalne distributivne pravednosti je taj da je tuzemna analogija na kojoj ona počiva u potpunosti pogrešna. Države među sobom nemaju ekvivalenta građanskom ugovoru te među njima vlada, kako je još davno Hobbes zamijetio, prirodno stanje. Ovaj stav je ujedno osnova realistične pozicije u teoriji međunarodnih odnosa.

Rawls, u svojem djelu Teorija pravednosti, također poriče bilo kakvu globalnu analogiju koja bi uspostavila kozmopolitsku društvenu pravednost nalik onoj unutar države. Državni sustavi distributivne pravednosti mogu postojati upravo zato što među građanima postoji osjet zajednice koja dijeli sudbinu. Takvo što, prema Rawlsu, ne postoji na globalnoj razini. Ne postoji svjetska zajednica u ovom kohezivnom smislu te samim tim nije moguća ni kozmopolitska društvena pravednost. Iz toga proizlazi da globalna država blagostanja ostaje puka tlapnja, štoviše, bilo bi nepravedno da od stanovnika bogatijih zemalja svijeta zahtijevamo brigu za dobrobit svjetskih siromaha samim tim što nema istinskog osjeta povezanosti među njima.

Cijela suvremena teorija globalne distributivne pravednosti zapravo se razvila kao odgovor na Rawlsove negativne argumente. Možda najuvjerljiviji odgovor Rawlsovim postavkama pružio je Charles Beitz koji u Political Theory and International Relations odbacuje dvije utjecajne teorije međunarodnih odnosa kao empirijski i teorijski pogrešne. ${ }^{9}$ Prva od njih je već spominjano shvaćanje da u međunarodnim odnosima vlada hobsovsko prirodno stanje u kojem moralnim prosudbama nije mjesto, te druga, da su države analogne pojedincima u građanskom društvu prema tome što posjeduju autonomiju koja ih štiti od vanjske moralne prosudbe i političkih utjecaja. On snažno tvrdi da je hobsovska koncepcija međunarodnih odnosa netočna jer svijet ubrzano postaje sve povezanija zajednica koja se prema svojim svojstvima približava zajednici građana unutar države. Zbog toga Beitz ne smatra da je tuzemna analogija načelno pogrešna, nego da je treba izmijeniti. Načelo državne autonomije treba biti uvjetovano na osnovi pravednosti institucija te iste države, a zbog sve većeg razvoja globalnog društva i s njim povezanog svjetskog građanstva, moralni argument protiv globalne distributivne pravde gubi svoju snagu.

\section{Osnove kozmopolitske demokracije}

Pitanje koje se često postavlja unutar suvremene globalizacijske teorije pitanje je li, zahvaljujući tehnološkom napretku sredstava komunikacije, prometnih sredstava te međunarodnih trgovinskih razmjena, nastala osnova za svjetsko društvo? A ako već postoji svjetsko društvo, je li osjećaj zajedništva toga društva dovoljno jak da bi se na njegovoj osnovi mogle izgraditi svjetske, a 
ne samo međunarodne upravljačke institucije. Također, $\mathrm{u}$ literaturi su česta $\mathrm{i}$ sporenja oko toga postoji li već takvo društvo te je li osjećaj zajedništva tog društva dovoljno jak da bi se na njegovoj osnovi mogle izgraditi kozmopolitske institucije, pa i sama kozmopolitska demokracija.

Jedan niz autora smatra da je za izgradnju ovih institucija dovoljno slaganje oko pitanja ljudskih prava. Tako Seyla Benhabib, slijedeći Hannu Arendt, pitanje ljudskih prava stavlja kao jedno od središnjih točaka cjelokupnog kozmopolitskog projekta:

»Ostavština zapadnjačkog racionalizma bila je rabljena i zlorabljena u službi institucija i praksi koje neće izdržati procjenu istog tog razuma za koji tvrdi da ga širi. Kako globus materijalno srasta u jedan svijet, postaje sve hitnije shvatiti kako zahtjevi za univerzalnošću mogu biti pomireni s izrazima religijske i kulturne različitosti; kako jedinstvo razuma može biti pomireno s raznolikošću životnih oblika. Javni vokabular kroz koji su ova pitanja najsnažnije artikulirana jest jezik ljudskih prava. Širenje ljudskih prava, kao i njihova obrana i institucionalizacija, postali su neosporavani jezik, premda ne i stvarnost, globalne politike. ${ }^{10}$

Benhabib se koristi frazom Hanne Arendt »pravo na imanje prava«, koje $\mathrm{u}$ njenom radu načelno slovi za političko pravo usko povezano s pravom članstva u političkoj zajednici, da bi ga preformulirala u koncept shvaćen kao zahtjev da svaka ljudska osoba bude prepoznata kao moralno biće vrijedno jednake brige i jednakih prava na zaštitu, kao pravna osoba, od njegove ili njene političke zajednice, ali također i svjetske zajednice. Benhabib dalje tvrdi da pravo na imanje prava uključuje priznavanje tuđeg identiteta kao univerzalnog, ali i kao konkretnog drugog.

Benhabib smatra da pozicija »univerzalnog drugog« zahtijeva od nas da gledamo na svaku pojedinačnu individuu kao biće koje ima pravo na ista prava i dužnosti koje bismo željeli pripisati sebi. U zauzimanju ovog stajališta, mi apstrahiramo individualnost i konkretni identitet drugoga. Mi pretpostavljamo da je drugo biće, poput nas samih, ono koje ima konkretne potrebe, želje i afekte, ali ono što sačinjava njegovo ili njezino moralno dostojanstvo nije ono što nas razlikuje jedne od drugih, nego ono što mi, kao govoreća i djelujuća i utjelovljena bića, imamo zajedno. Naš je odnos prema drugome vođen normama formalne jednakosti i recipročnosti: svatko ima pravo od nas očekivati ono što mi očekujemo od njega ili nje. U odnošenju prema tebi u skladu s ovim normama ja potvrđujem u tvojoj osobi prava čovječanstva i imam legitiman zahtjev da ćeš $i$ ti to isto činiti u odnosu na mene.

Pozicija »konkretnog drugog« od nas, pak, zahtijeva da gledamo na svako pojedinačno biće kao individuu s afektivno-emocionalnim ustrojem, konkretnom poviješću i individualnim, kao i kolektivnim identitetom, a u mnogim slučajevima i s imanjem više od jednog takvog kolektivnog identiteta. U zauzimanju takvog stajališta, mi ograđujemo ono što čini naše zajedništvo i fokusiramo se na pojedinačnost. Naš odnos s drugim vođen je putem normi pravednosti i komplementarne recipročnosti. U ovom slučaju, naše razlike se prije komplementiraju, negoli isključuju jedna drugu. U odnosu prema tebi u skladu s ovim normama, potvrđujem ne samo tvoju čovječnost nego i tvoju ljudsku individualnost. Ako stajalište poopćenog drugog izražava normu poštovanja, onda konkretnost drugog predviđa iskustva altruizma i solidarnosti. Stoga Benhabib zaključuje:

Charles R. Beitz, Political Theory and International Relations, Princeton University Press, Princeton, NJ 1999.
10

Seyla Benhabib, Dignity in Adversity. Human Rights in Troubled Times, Polity Press, Cambridge 2011., str 59. 
»Ako te priznajem kao biće koje ima pravo na prava samo zato što si poput mene, tada poričem tvoju fundamentalnu individualnost koja te čini različitom. Ako odbijam priznati te kao biće koje ima pravo na prava zato što si različit od mene, tada poričem našu zajedničku humanost. « ${ }^{11}$

Obje su ove sastavnice nužne da bismo posjedovali ono što nazivamo ljudskim pravima.

No ljudska prava, kako ih danas poznajemo, definiraju i minimum koji se treba održavati, kao i maksimum kojem bismo trebali težiti. Zbog toga će, tvrdi Benhabib, uvijek postojati rasprava o njihovu značenju kao i o njihovu opsegu. Stoga, bez obzira kakvu listu ljudskih prava složili, ona će uvijek nužno biti nepotpuna. Nove moralne, političke i kulturne borbe izbacit će nova prava za stavljanje na listu te će time proširiti maksimum kojem bi ljudi trebali težiti.

»Upravo zato što proizlaze iz takvih borbi i procesa učenja, dokumenti ljudskih prava ne mogu jednostavno utjeloviti preklapajući konsenzus ili minimalne uvjete legitimnosti; oni daju glas nastojanjima duboko podijeljenog čovječanstva postavljajući jedinstveni standard postignuća za sve narode i nacije. ${ }^{12}$

Dok autori poput Seyle Benhabib smatraju da bi samo poštovanje ljudskih prava trebalo biti dovoljno za organizaciju nekog oblika kozmopolitske vladavine, dio autora drži da je za takvo što potrebno mnogo više. To »mnogo više« jest osjećanje solidarnosti sa svjetskom zajednicom, nešto što kozmopolitizam u svom etičkom obliku zagovara već više od dvije tisuće godina, a čini se kako još uvijek nije uvjerio dovoljno pripadnika ljudske vrste. To ipak ne znači da nikakav oblik globalne solidarnosti ne postoji. Jačanjem međunarodnih nevladinih organizacija, poput Greenpeacea ili Amnesty Internationala u 1970-ima, mnoga pitanja koja su prije bila isključivo predmet nacionalnih država postala su dostupna prosudbi svjetske javnosti. U osamdesetima je, pak, humanitarna pomoć putem Live Aida pretvorena u globalni spektakl. Ako je taj spektakl i bio samo »svjetla i dim«, koji nije uspio značajno promijeniti živote onima kojima je pomoć bila potrebna, on je promijenio mnoge živote onih u »sretnijim« zemljama svijeta, učinio ih je svjesnijima njihove odgovornosti prema svijetu u cjelini. Danas postoji cijeli niz priredaba $\mathrm{i}$ organizacija koje ukazuju na našu potrebu za globalnim promišljanjem - od onih koje se bave ekološkim pitanjima do onih koji se bave osobnim slobodama ili pitanjima distributivne pravednosti. Ipak, uspostava globalne zajednice zahtijeva puno jači oblik globalne solidarnosti.

Značajno razmatranje koncepta solidarnosti dao je Hauke Brunkhorst u knjizi Solidarnost. ${ }^{13}$ On tvrdi da moderno shvaćanje demokratske solidarnosti potječe od parole bratstva jakobinske revolucije. No za razliku od bratstva, sam pojam solidarnosti uvelike nadilazi pozivanje na osjećaj supripadnosti, on je jedan od rijetkih koncepata moralnog mišljenja koji se pokazao uskladivim s modelom političkog zajedništva. Stoga Brunkhost zaključuje da se

»... ne čini potpuno bezglavim nadanje da bi taj koncept iz komunikacijskog životnog svijeta mogao biti dorastao i apstraktnim procesima globalne sistemske integracije. «14

\section{Brunkhorst tako tvrdi da su za Francuske revolucije}

»... pod parolom bratstva jakobinci politizirali jednakost. Ako su svi rođeni s jednakim pravom na slobodu, onda bi svi trebali i sudjelovati u javnim pitanjima. Fraternité se poistovjećuje s république - a obje pak s demokracijom - i usmjerava prema institucionalnom, zakonskom ukorjenjivanju. « ${ }^{15}$

Ova politizacija ukida dualizam između božje i građanske države, a s njime i oblik hijerarhijske solidarnosti svojstven srednjem vijeku. Značenje jednake 
građanske slobode se umrežavanjem s bratstvom pomiče od elitističkog statusa prema egalitarističkom univerzalizmu. Jakobinski patriotizam ljudskih prava stoga postaje prvi egalitarni oblik ljudske solidarnosti - nejednakosti u vlasništvu i marljivosti su poput nejednakosti u dobi, spolu, boji kože, a one se ne tiču jednakosti građanstva. Građani republike tako više ne moraju poput građana polisa jedni drugima biti naklonjeni niti ljubiti jedni druge kao kršćani. Brunkhorst dalje tvrdi da je s republikanskom nacionalnom državom prvi put u povijesti postalo politički moguće organizirati egalitaristički oblik solidarnosti koji je sezao daleko preko granica urbanog građanskog društva i dvorskih plemstava. Ova ideja nije unaprijed bila partikularistički ograničena na granice svake pojedine države, niti je bila u savezu s nacionalizmom i imperijalizmom. Ona je prije ukazivala na model globalne solidarnosti republika jednakih prava, na koju će ukazati i Kant u spisu Prema vječnom miru.

No danas, pod naletom globalizacijskih promjena, raspadaju se ovi oblici nacionalne solidarnosti. Dok svjedočimo sve većem slabljenju socijalnih država, oko nas postaju sve jače institucije sigurnosne države. Prema Brunkhorstovu mišljenju, ovi su problemi stjerali demokraciju u defenzivu u trenutku kada se činilo da će ona zavladati cijelim svijetom, te da će, kao politička ideja i ustavni oblik, praktično ostati bez alternative. Ali to ne znači da je državno organizirana demokracija na izmaku, niti da nema izgleda za uspostavu globalne demokracije. Bez demokracije u svijetu država, između država i preko tog svijeta država, nema ni globalne solidarnosti.

Brunkhorst na kraju svog razmatranja ideje solidarnosti dolazi do zaključka sličnog McLuhanovom. Globalna pozitivizacija ljudskih prava i sve veći odjek slabe svjetske javnosti tek su omogućeni tehničkom revolucijom elektroničkih medija i zračnog prometa od sredine 20. stoljeća. Stoga Brunkhorst zaključuje:

»Bez pisma nema urbane republike, bez tiska nema modernog državnog ustava, a bez elektroničkih medija nema transnacionalnih prava čovjeka i građanina svijeta koji bi bili više od apela, zahtjeva, 'oda' i 'svečanih proglasa' [...]. Tek kada na raspolaganju stoje tehnički mediji globalne komunikacije, idealna komunikacijska zajednica svih ljudi počinje se preobražavati u stvarnu. Ljudska prava, demokracija i globalna solidarnost preobražavaju se od 'utvare' u 'povijesni pokret' $[\ldots] . «^{16}$

Ovaj optimistični pogled na ljudsku solidarnost, koji svoju svrhu ima u ispunjenju globalne zajednice, kritički sagledava Miščević koji tvrdi, pomalo pesimistično, da čak ako bismo se i složili s nekom shemom globalne solidarnosti, današnje je svjetske institucije ne bi mogle provesti u djelo. Stoga su jedan od glavnih uvjeta za globalnu solidarnost mnogo čvršće institucije.

»Kao što solidarnost unutar države traži djelotvorni aparat poreza, preraspodjele, te društvene kontrole ustanova poput zdravstva, školstva i slično, tako bi i ozbiljna globalna solidarnost tražila reorganizaciju svjetske zajednice. $^{17}$

11

Ibid., str. 69.

12

Ibid., str. 72 .

13

Hauke Brunkhorst, Solidarnost: Od građanskog prijateljstva do globalne pravne zajedni$c e$, Beogradski krug, Multimedijalni institut, Beograd, Zagreb 2004.
14

Ibid., str. 14.

15

Ibid., str. 77.

16

Ibid., str. 194.

17

Nenad Miščević, Nacionalizam - etički pogled, KruZak, Zagreb 2006., str. 310. 
I time zapravo ulazimo u krug. Globalne institucije ne mogu ispravno djelovati bez informiranosti globalnim normama, a globalne norme ne mogu se provesti bez globalnih institucija. Ili, da parafraziramo jednu drugu rečenicu poznatu iz povijesti filozofije, globalne institucije bez globalnih normi su slijepe, a globalne norme bez globalnih institucija su prazne.

\section{Ako ne demokracija...?}

Prijedlozi za uspostavu globalne vladavine nisu izum našeg doba. Danteova je De monarchia svakako prvi od prijedloga, ali u djelu nema ni riječi o nekakvoj globalnoj demokraciji. U osamnaestom stoljeću postoji cijeli niz prijedloga "globalnog upravljanja«, no malo je njih zaokupljeno s demokratskim procedurama odlučivanja. Sve nas ovo navodi na zaključak da zbilja nije nužno da oblik globalne vladavine bude demokratski te da je lako zamisliti druge modele koji bi bili barem podjednako, ako ne i više djelotvorni. Da bi objasnio modele svjetskog poretka, Miščević ih svrstava u tri osnovne grupe. Uz kozmopolitsku demokraciju, koju on naziva modelom kozmopolitske utopije, on još prepoznaje puni nacionalni model te umjereno nadnacionalni model globalnog upravljanja.

U punom nacionalnom modelu samostalnih suverenih država, uloga nadnacionalnih tijela ili zajednica svedena je na najmanju moguću mjeru. Ovaj model često se brani takozvanom realističkom pozicijom u teoriji međunarodnih odnosa, čija je osnovna postavka da se politika ne smije miješati s etikom, nego je treba mjeriti vlastitim mjerilima političke realnosti koja se temelje na različitoj distribuciji moći. Drugi je model umjereno nadnacionalni, odnosno model saveza država. Ovaj model priznaje ulogu neke vrste međunarodnog društva naroda kao i neke osnovne norme međunarodnog prava. Međunarodno pravo ovdje služi da bi se ograničila potpuna autonomija država u odlučivanju, a ova se pozicija smješta negdje na pola puta između politike i etike. Kao što Miščević duhovito kaže, "malo etike može, ali ne pretjerujmo«. ${ }^{18}$ I Kantov prijedlog u Prema vječnom miru, kao i Rawlsov u Pravu naroda spadaju u ovu skupinu.

Treba upozoriti i na opasnosti koje bi ideju kozmopolitske demokracije mogle odvesti krivim putom. Prva je od njih opasnost od jednačenja kozmopolitske demokracije s kapitalističkim restrukturiranjem svijeta prema neoliberalnoj osnovi. Peter Gowan tako upozorava: bude li kozmopolitski projekt unifikacije čovječanstva pogonjen shvaćanjem kapitalističkih država o širenju slobodnog tržišta,

»... na normativnoj osnovi da smo svi pojedinačno globalni građani s liberalnim pravima neće djelovati: vjerojatnije je da će baciti Planet u sve više razdvajajući metež. «19

Sličnom se stavu priklanja i Craig Calhoun koji tvrdi da treba biti oprezan jer kozmopolitizam, premda predstavlja projekt revitalizacije klasičnog liberalizma, uistinu je i projekt kapitalizma i »cvjeta na visokim upravljačkim pozicijama multinacionalnih korporacija te čak i više, u konzultantskim tvrtkama koje im služe . $^{20}$ Ova vrst kozmopolitizma udružuje elite preko nacionalnih granica, dok obični ljudi nastavljaju živjeti u lokalnim zajednicama. To nije zato što su oni manje skloni raznolikosti, što je, kako Calhoun tvrdi, ideja kojom si laskaju elite, nego je to zato što klasno strukturiranje javnog života isključuje sve one koji ne pripadaju toj eliti.

Kapitalizam je jedan od ključnih čimbenika globalizacije, koja je, pak, glavni razlog zbog kojeg se danas javljaju pozivi na stvaranje kozmopolitskih institucija. Calhoun tvrdi da bi bilo pogrešno slijediti kozmopolitizaciju ako ona 
vodi u suprotnost s lokalnim solidarnostima ili ako ona ne bude primjereno razlikovana od kapitalističke agende. Prizivanje na apstraktna ljudska prava nije dovoljno za izgradnju kozmopolitskog društva. Calhoun tako kaže:

»Izgradnja kozmopolitizma samo na takvom diskursu individualnih prava - bez stroge pažnje spram raznolikih solidarnosti i borbe za pravedniji i demokratskiji društveni poredak - također ulazi u opasnost zamjenjivanja etike za politiku. Učinkovita populistička politika mora naći korijene $\mathrm{u}$ društvenim grupama i mrežama veza među njima. $\ll^{21}$

Neoliberalizam je, pak, prema Calhounu, vrsta međunarodne agende koja se predstavlja kao nužnost u odnosu na koju svi ljudi, organizacije i države nemaju izbora nego se prilagoditi. Proces integriranja u Europsku uniju često se zemljama pristupnicama prikazivao kao nužan odgovor na globalne ekonomske procese. Ipak, transnacionalni odnosi ne moraju biti izgrađeni baš na ove načine. Treba shvatiti da postojeće lokalne i nacionalne institucije nisu samo nasljeđe tradicije nego i teško dobivena postignuća društvenih borbi. Stoga obrana takvih institucija nije uvijek znak zaostalosti.

Kao praktični projekti, kozmopolitizam i demokracija oboje su bili, i još uvijek jesu, povezani sa zapadnjačkim pogledom na svijet, koji uključuje kako kapitalizam, tako i kulturni elitizam. Calhoun stoga upozorava da se kozmopolitska demokracija, ako želi napredovati, mora osloboditi svojih ukorijenjenih stavova. Mora se razdvojiti od neoliberalnog kapitalizma, kao i podcjenjivačkog pogleda prema svim kulturama koje ne zadovoljavaju zapadnjačke »standarde«. Stoga treba pristupiti prekokulturnim odnosima i konstrukciji društvenih solidarnosti s dubljim priznavanjem značaja različitih početnih točaka te njihovih mogućih rezultata. Treba omogućiti uključivanje različitih diskursa, posvetiti se s više predanosti ukidanju materijalne nejednakosti, te biti više otvoren prema korjenitoj promjeni. Calhoun osuđuje mnoge zagovornike kozmopolitske demokracije zato što, poput liberala u prošlosti, često nude viziju političke reforme privlačne elitama, onu koja obećava pronalazak vrline bez radikalnih promjena vezanih uz redistribuciju bogatstva ili moći. Stoga zaključuje da je ovo posebno neugodno za položaje političke ljevice u naprednim kapitalističkim zemljama. Oni koji zagovaraju radikalnu promjenu često napadaju i zapadnu kulturu i vrijednosti, među kojima je i liberalizam, kao izvor globalne nejednakosti.

Calhoun govori da rješenje ovog problema sigurno nije u prihvaćanju neliberalnih nacionalizama ili fundamentalizama. Oni mogu dati glasa potlačenima a da istovremeno ne budu i glasovi dobra. Ali također tvrdi da »nije sav nacionalizam ružni etnonacionalizam; nije sva religija fundamentalizam «. ${ }^{22}$ I nacionalizam i religija mogu biti izvorima solidarnosti i brige za strance. Stoga Calhoun zaključuje

»... ako kozmopolitska demokracija želi biti nešto više od dobre etičke orijentacije za one privilegirane koji nastanjuju salone redovitih letača, ona mora pustiti korijenje u solidarnostima koje oblikuju osjećaje identiteta i mjesta u svijetu većine ljudi. «²3

18

Ibid., str. 325 .

19

Peter Gowan, »The New Liberal Cosmopolitanism«, u: D. Archibugi (ur.), Debating Cosmopolitics, str. 64 .

20

Craig Calhoun, »The Class Consciousness of Frequent Travellers: Towards a Critique of Actually Existing Cosmopolitanism«, u: D.
Archibugi (ur.), Debating Cosmopolitics, str. 108-109.

21

Ibid., str. 110.

22

Ibid., str. 112.

23

Ibid. 
Druga velika opasnost za uspostavu kozmopolitske demokracije jest demokratski deficit. U globalnim centrima moći donose se odluke koje imaju posljedice na veliki broj svjetskih građana, ali oni koji donose odluke skoro nikad nisu bili izabrani, ne mogu biti uklonjeni kroz demokratske procese i ne odgovaraju ni na koji način onima koji su podložni učincima njihovih odluka. Ukratko, svi elementi demokracije nedostaju i stoga ne postoji mogućnost promjene kroz demokratske procese na nacionalnoj razini. Globalizacija je učinila to da nacionalna država više ne može djelovati kao zaštitna ovojnica svojim građanima od problema svijeta te joj je time otežala provođenje njenog ugovora s građanima.

Tome bismo se mogli suprotstaviti uspostavom višerazinskih oblika vladavine koji će odlučivanje raspodijeliti na lokalna, regionalna i kontinentalna tijela. Uz ovakvu diferencijaciju u razinama odlučivanja, autori poput Davida Helda ili Richarda Falka smatraju da bi se na problem demokratskog deficita na globalnoj razini najbolje odgovorilo uspostavom neke vrste svjetske parlamentarne skupštine. Ostaje upitno je li moguće stvaranje ovakve parlamentarne skupštine na ovom stupnju povijesti, no pretpostavimo da ta nemogućnost nije apsolutna, odnosno da će se jednom u budućnosti moći ostvariti uvjeti koji bi doveli do ovog koraka u izgradnji globalne demokracije. Uistinu, Europska unija na određeni način predstavlja empirijski nagovještaj ovog globalnog projekta koji, usprkos brojnim nedostatcima, pokušava nadvladati taj demokratski deficit.

Sama Europa je mnogo kulturno i ekonomski homogenija od svijeta općenito, a uspostava Europskog parlamenta donijela je toj instituciji samo simboličnu, a ne pravu moć odlučivanja, koja još uvijek ostaje u rukama nacionalnih država, odnosno ministara na ministarskim sastancima. Ipak, usprkos problemima, primjer Europske unije pokazuje da ne postoje apsolutne političke ili logističke prepreke uspostavi takve skupštine na globalnoj razini te da ovakav razvoj ne znači i dokidanje postojećih nacionalnih država i nacionalnih osjećaja. Iako ovo daje nadu u razvoj kozmopolitske demokracije, u dosadašnjoj se praksi ovakva decentralizirana vladavina pokazala manje demokratskom nego nacionalne vladavine u suverenoj državi. Europska unija i Ujedinjeni narodi prije svega su birokratske, a ne demokratske institucije.

Veliki izazov za uspostavu kozmopolitske demokracije neće biti samo izbjegavanje prevladavajuće tehnokratske orijentacije koja vlada današnjim međunarodnim institucijama. Također, veliki problem predstavljat će i snažna suprotstavljanja između liberalnih i radikalnih kozmopolitskih vizija. Ako projekt za uspostavu kozmopolitske demokracije njih ne bude bio svjestan, lako se može dogoditi da retorika kozmopolitizma bude iskorištena za podršku, kako ih Ulrich Beck naziva, deformiranih vizija kozmopolitizma. Stoga Calhoun dobro primjećuje kada kaže da

»... 11. rujna 2001. teroristi koji su srušili zrakoplove u Svjetski trgovački centar i Pentagon zadali su udarac kozmopolitizmu - možda čak i uspješnije nego nad njihovim očitijim simboličkim ciljevima, nejednakim strukturama globalnog kapitalizma i političke moći.« ${ }^{24}$

No i prije 11. rujna bilo je jasno da oni, čiji zahtjevi za sudjelovanjem nisu udovoljeni, neće prihvatiti legitimnost postojećih institucija svjetskog sustava. Ako se to nastavi, čini se izglednim da će doći do jačanja nestabilnosti koje, čak, mogu dovesti do potencijalnog svjetskog sukoba.

Konačno, trebalo bi upozoriti na još jednu od posljedica demokratskog deficita koja ga samo dodatno produbljuje. Paradoks suvremene demokracije leži u tome da, kako se ona sve više širi svijetom u zrelim demokracijama Zapada, 
koje se ostatak svijeta trudi oponašati, istovremeno dolazi do sve većeg razočaranja u demokratske procese. Povjerenje u političare opada, sve manje ljudi izlazi na birališta, a sve više mladih ljudi ili ne zanima parlamentarna demokracija ili zagovaraju teško ostvarive modele direktne demokracije. Politički prostor postaje sve ispražnjeniji i sve pogodniji za grube manipulacije različitih oblika. Ovaj procjep, u kojemu jedni imaju mogućnost sudjelovati u odlučivanju, a ne iskorištavaju je, a drugi pak žele, a nije im omogućeno, nešto je što će kozmopolitska demokracija morati zatvoriti da bi omogućila ispunjavanje svih proklamiranih kozmopolitskih ciljeva poput slobode, jednakosti i stabilnog političkog sustava pogodnog za razvoj sposobnosti pojedinca.

\section{Ostvarivanje globalne pravednosti putem kozmopolitske demokracije}

Je li kozmopolitska demokracija uistinu politička utopija? Čine li sve ranije nabrojane prepreke uistinu ovaj projekt nemogućim? Postoji li uopće način na koji bismo mogli ostvariti upravljiv globalni sustav koji bi bio odgovoran svakom pojedinom čovjeku? Ako i postoji, hoće li on omogućiti postizanje globalne pravednosti? Vezano uz ovaj problem, trebamo imati u vidu da ne postoji zajednica koja bi mogla poslužiti kao idealna svim ljudima zato što postoji široka lepeza koncepcija o najboljem mogućem uređenju društvenog prostora.

Stoga se čini da je problem za uspostavu kozmopolitske demokracije to što se različite kozmopolitske vizije neupitno sukobljavaju jedna s drugom, s obzirom na to da se svaka od njih obično drži za jedinstvenog čuvara konačne istine. Zahvaljujući tome, usprkos iskrenim težnjama za jedinstvom ljudske vrste, kozmopolitski se projekti nalaze u opasnosti da budu iskorišteni kao oruđa za opravdavanje imperijalističkih akcija koje bi bile opravdane »sukobom među civilizacijama« i raznim vrstama »humanitarnih intervencija«. Stoga Daniele Conversi zaključuje:

»Ako je jedini ostvarivi racionalni cilj ljudska koegzistencija, onda kozmopolitizam može bit samo osmišljen kao nekompatibilan s homogenizacijom i uistinu sa suvremenom globalizacijom. $\ll^{25}$

Da bi se ostvarila ta koegzistencija, Held tvrdi da je potrebno iznova promisliti značenje i mjesto demokracije na nizu lokalnih, regionalnih i globalnih struktura i procesa koji se preklapaju. On smatra da postoje barem tri ključne posljedice globalizacije koje je u tu svrhu bitno usvojiti:

»Prvo, način na koji procesi ekonomske, političke, pravne i vojne međupovezanosti odozgo mijenjaju prirodu suverene države; drugo, način na koji lokalni i regionalni nacionalizmi nagrizaju naciju-državu; treće, način na koji globalna međupovezanost stvara lanac uzajamno uvjetovanih političkih odluka i rezultata među državama i njihovim građanima, što mijenja prirodu i dinamiku samih nacionalnih političkih sustava. Demokracija se mora nositi sa sva tri procesa i njihovim posljedicama za nacionalna i internacionalna središta moći.« ${ }^{26}$

24

Ibid., str. 86.

25

Daniele Conversi, „Cosmopolitanism and Nationalism«, u: Athena Leoussi (ur.), Encyclopedia of Nationalism, Transaction Books, New Jersey 2001., str. 39.
26

David Held, Modeli demokracije, Školska knjiga, Zagreb 1990., str. 331. 
Kako se demokracija i aktivna vlada mogu održati kada se čini da su ih ovi procesi učinili potpuno beskorisnima? Anthony Giddens ih naziva demokratizirajućom demokracijom. Također, smatra kako današnja demokracija mora postati nadnacionalna jer demokratizacija je potrebna iznad kao i ispod nacionalne razine:

»Globalizirajuće doba zahtijeva globalne odgovore, a to se odnosi na politiku koliko i na bilo koje drugo područje. $\ll^{27}$

Giddens smatra da bismo, također, trebali biti spremni na eksperimente s alternativnim demokratskim procedurama, osobito ako bi one pomogle približavanju procesa donošenja političkih odluka građanima i njihovim svakodnevnim brigama. Narodne porote ili elektronički referendumi, naprimjer, neće zamijeniti predstavničku demokraciju, ali mogu poslužiti kao korisni dodaci. Giddens zaključuje da se za unapređenje demokracije na svim razinama vrijedi boriti, te da je ono moguće:

»Našem odbjeglom svijetu ne treba manje, nego više vlasti - a to mogu pružiti samo demokratske institucije. $\ll^{28}$

Taj oblik »više vlasti« predstavlja i Europska unija. Proces europske integracije zapravo bismo trebali nazvati aktualizacijom društvenog eksperimenta budućeg svjetskog poretka. Kako Nadia Urbinati primjećuje, ova ideja je

»... kćer vizije mirne Europe naseljene demokratskim nacijama koje su inspirirale europske intelektualce od vremena prosvjetiteljstva do vremena demokratskih revolucija 1848. Kao podzemna struja, ova je vizija povezivala Kantov kozmopolitski liberalizam i kozmopolitsko pravo naroda Giuseppea Mazzinija. ${ }^{29}$

Europska politička integracija ovoj staroj ideji udahnula je novi život te, štoviše, povratno inspirira teoretičare koji se bave poljem kozmopolitske demokracije. Stoga i nije slučajnost da su primarni zagovornici kozmopolitske i postnacionalne demokracije uglavnom Europljani.

Daniele Archibugi je jedan od tih Europljana koji budućnost svijeta vidi kao preslikanu i proširenu europsku postnacionalnu demokraciju. Ipak, on je također svjestan da se, u svjetlu političke filozofije duge dva tisućljeća, može činiti čudnim naići na pojmove 'demokracija' i 'kozmopolitizam' spojene zajedno. Demokracija predstavlja vladavinu mnoštva, odnosno većine u tom mnoštvu. Ona je nastala kao sredstvo za rješavanje konkretnih problema političke zajednice - koga postaviti na vlast, kako ubirati poreze i kako novac od njih trošiti, kako odrediti one koji će se brinuti za obranu i djelotvornost zajednice i drugo. Bitno svojstvo demokracije je i to da svi sudionici u njoj moraju biti pripadnici iste zajednice. Do unazad nekoliko stoljeća, članovi postojećih demokracija, bilo da su oni grčki polisi ili talijanski republikanski gradovi, znali bi jedni druge po viđenju.

Kozmopolitizam, kao što smo vidjeli, jednako je drevan pojam kao i demokracija, ali od početka se odnosio na ideju, a ne na stvarno stanje. Ideja da je pojedinac građanin svijeta ili, pak, da cijeli svijet može postati njegov polis prije je bila pojedinačna težnja nego stvarnost mnoštva.

»Samo trgovci, vojnici, pokoji intelektualac i nekoliko moćnika bili su upoznati sa zemljama, gradovima i ljudima izvan njihovih rodnih zajednica. Svi ostali, većina - drugim riječima, demos - mogli su samo zamišljati kakvi su drugi dijelovi Planeta putem legendi i priča putnika. « ${ }^{30}$

No čak i u današnjem masovnom društvu epitet »kozmopolitski« ne može biti primijenjen na demos, na većinu. U informatičkom dobu u kojem živimo, čak trećina stanovnika našeg planeta još uvijek nikad nije koristila telefon, stoga 
nije nimalo iznenađujuće što kozmopolitizam još uvijek ostaje privilegij elite. Archibugi primjećuje da je zanimljivo da su oba termina, premda svoje postojanje duguju istoj tradiciji, ostali tako odlučno razdvojeni tijekom stoljeća. Možda je razlog ove razdvojenosti ležao u intrinzičnoj razlici između njihovih društvenih referentnih točki: dok je jedno govorilo o mnogima, narodu, drugo je implicitno evociralo privilegije nekolicine.

S političke se ljevice često čuje da je projekt demokratskog kozmopolitizma zapravo nastavljač ideje proleterskog internacionalizma koji je pretpostavljao besklasni svijet bez ratova te $u$ kojem zajednica u kojoj vladaju radnici ne bi imala potrebu pokoravati neku drugu. Kao posljedica toga, suverenost bi nestala zajedno sa svojom nositeljicom, nacionalnom buržoaskom državom. Da bi ostvario kozmopolitsku demokraciju, Archibugi poziva na ponovno promišljanje njegova političkog programa, ali i čuvanje duha proleterskog internacionalizma. Stoga kozmopolitska demokracija, za razliku od internacionalizma, predlaže stvaranje institucija i kanala predstavljanja za sve pojedince, a ne za samo jednu klasu. Cilj kozmopolitske demokracije nije ukidanje klasa, nego nešto puno skromnije, osiguravanje da su zahtjevi građana izravno predstavljeni u globalnim pitanjima. To znači da odluke na globalnoj razini treba donositi većina, a ne jedna klasa - bili to bogati industrijalci, političari, radnici ili netko četvrti. Iz tog razloga, parafrazirajući »Komunistički manifest«, Ulrich Beck izdaje novi poziv:

»Kozmopoliti cijelog svijeta, ujedinite se! « ${ }^{31}$

Pogled s ljevice na kozmopolitsku demokraciju upotpunjava i David Held, koji kao pogodan model za njegovu uspostavu predlaže »participativnu demokraciju«. Ovaj model drži da se razvitak pojedinca može postići samo u participativnom društvu koje istovremeno potiče osjećaj političke djelotvornosti, jača zanimanje za zajedničke probleme te pridonosi stvaranju upućenog građanstva, voljnog i sposobnog da se trajno bavi procesom vlasti. Od građana participativne demokracije očekuje se da izravno sudjeluju u bitnim ustanovama društva, što uključuje njihovo radno mjesto kao i lokalnu zajednicu. Od stranaka unutar sustava participativne demokracije očekuje se veća odgovornost kako prema članstvu, tako i prema političkoj zajednici u cjelini. Ove bi stranke djelovale u sklopu parlamentarne strukture, ali bi sustav bio otvoren i za razne institucionalne oblike kojima bi se omogućilo veće sudjelovanje članova cjelokupne zajednice. Nije teško uočiti da ovaj Heldov prijedlog zapravo pokušava spojiti ono što se smatra najboljim svojstvima prijašnjih demokratskih modela, tako da se ispunila dva glavna uvjeta - legitimnost i učinkovitost.

Ali, kako i Held uočava, premda participativna demokracija priznaje i rješava mnoge poteškoće vezana uz tri ranija demokratska modela, ovaj model ostavlja neriješenim nekoliko temeljnih pitanja, uključujući i ono kako osigurati

27

Anthony Giddens, Odbjegli svijet, Naklada Jesenski i Turk, Zagreb 2005., str. 82-83.

28

Ibid., str. 88 .

29

Nadia Urbinati, „Can Cosmopolitan Democracy Be Democratic«, u: D. Archibugi (ur.), Debating Cosmopolitics, str. 70-71.
30

Daniele Archibugi, »Demos and Cosmopolis «, str. 257

31

Ulrich Beck, »The Cosmopolitan Manifesto«, u: Garrett W. Brown i David Held (ur.), The Cosmopolitanism Reader, Polity Press, Cambridge 2010., str. 228. 
adekvatne uvjete vlastitog postojanja. Također, iako se sudjelovanju učimo sudjelujući, te iako participacija pomaže stvaranju aktivnog i upućenog građanstva, nema dokaza u prilog tome da će veće sudjelovanje u demokratskim institucijama samo po sebi potaknuti preporod u razvoju čovjeka. Held tako tvrdi:

»Ne bi bilo razborito računati na to da će ljudi općenito postati demokratskiji, kooperativniji i odaniji 'zajedničkom dobru'. Bit će vjerojatno pametnije pretpostaviti - osobito u procjeni suvremene relevantnosti konkurentskih modela demokracije - da se ljudi neće, kako je to prikladno rekao jedan komentator, "ponašati moralno ili intelektualno bitno bolje nego što se ponašaju danas'. $\ll^{32}$

Svjestan ove činjenice, Held u novijim radovima daje detaljnije prijedloge za uspostavu svjetske demokracije. Tako u Cosmopolitanism - Ideals and Realities izlaže plan za usmjeravanje svjetske politike u kozmopolitskom smjeru. ${ }^{33}$ Plan se sastoji od kratkoročnih i dugoročnih ciljeva, koje, pak, dijeli na one vladavine, sigurnosti, ekonomije i zaštite okoliša. Lista je poduža i uključuje mnogo toga: od reforme UN-a do globalne zaštite okoliša. Uzeto zajedno, ona se može činiti samo kao »lista dobrih želja«, ali također predstavlja i dobar praktični smjerokaz za potencijalni razvoj kozmopolitske demokracije.

Na kraju, mogli bismo se još jednom zapitati, s obzirom na sve iznesene zapreke, ima li kozmopolitska demokracija uopće šansu? Države koje u sklopu svojih granica obuhvaćaju više od jedne kulture nužno se suočavaju s problemom pravednosti. Naime, država kao takva ne može biti pravedna prema svima njima, odnosno ne može biti pravedna na isti način baš zato što različite kulture imaju različite koncepte pravednosti. Ako težimo svjetskoj državi, bila ona u federalnom ili konfederalnom obliku, kako bismo postigli globalnu pravednost, očita je potreba jedne »univerzalne« kulture. Univerzalna je kultura nešto prema čemu su suvremeni kozmopolitski pogledi sve skeptičniji jer njenim mogućim nastankom gubi se niz vrijednosti posebnih kultura, odnosno gube se cijeli »svjetovi« u kojima su ljudi živjeli. Pripadnost kulturi neraskidivo je povezana s konstrukcijom identiteta, kako pojedinaca tako i cijelih skupina, od usko lokalnih, pa sve do nacionalnih i civilizacijskih.

Kako riješiti ovaj problem? Kako uspostaviti globalno društvo s općim načelima pravednosti, a pritom ne rastočiti posebnosti kultura? Jedan od prijedloga za rješenje svakako bi bilo to da se identitet pojedinaca počne drukčije shvaćati, puno fluidnije i slojevitije. U skladu s Parekhovim prijedlogom, ${ }^{34}$ identitet pojedinca bi se trebao promatrati na tri razine - osobnoj (koja je uglavnom nepromjenjiva od rođenja), grupnoj (pripadnosti naciji, kulturi i civilizaciji) te kozmopolitskoj (pripadnosti ljudskim bićima), kako bi se na osnovi nje mogla razviti slojevita globalna kultura.

Drugi bi korak svakako trebala biti transformacija ljudskih prava u kozmopolitska prava. Dosadašnja ljudska prava još uvijek su, kako mnogi kritičari navode, »lista dobrih želja«. Trebamo njihovu jasniju definiciju, kodifikaciju, kao i čvršće i odlučnije globalne institucije koje bi se brinule o njihovoj zaštiti i pridržavanju. Tek kad budemo imali građane svijeta zaštićene kozmopolitskim zakonom moći ćemo i izgraditi svjetsku državu.

Ali najveća slabost suvremenog političkog kozmopolitizma možda je upravo njegovo isključivo naslanjanje na prava. Da bi kozmopolitizam postao idejna snaga koja bi mijenjala svijet oko nas, osim prava svjetskog građanina, trebali bismo više pozornosti posvetiti i obvezama svjetskog građanina. Teoretičari poput Helda i Heatera odavno predlažu novu Povelju o ljudskim pravima i odgovornostima, koja bi ukazala na potrebnu reformu globalnih institucija 
kao što su Ujedinjeni narodi. Ova bi povelja trebala pružiti osnovu za organizaciju globalnog pravnog sustava koji bi obuhvatio kazneno pravo, kao i međunarodno privatno pravo.

Uistinu, nacrt takve povelje zaista postoji, no ona nije proizvod neke svjetske političke institucije, nego lobističke grupe InterAction Council, čija je intencija bila taj nacrt predložiti na 50. godišnjicu proglašenja Opće deklaracije ljudskih prava. ${ }^{35}$ Sama namjera ove nove deklaracije bila je nadopuniti originalnu kako bi se ona ojačala i omogućila nastanak boljeg svijeta. Deklaracija o ljudskim odgovornostima još uvijek nije donesena. Zašto je tomu tako možemo samo nagađati. Je li riječ o nedovoljnom lobiranju, inerciji velikih međunarodnih organizacija ili pak, što je možda i najgore, protivljenju »velikih nacija« u čijem interesu nije veća odgovornost prema međunarodnoj zajednici, vjerojatno nikad nećemo saznati. Ali sama ideja postoji. Bilo bi začuđujuće da se jednog dana ne ostvari.

Na kraju, ostaje pitanje je li za svjetsku političku zajednicu potrebna demokracija? Kao što su tiskani mediji omogućili naciju kao imaginarnu zajednicu, kao što to tvrdi Benedict Anderson, mogli bismo reći da je i pojava Interneta stvorila mogućnost za uspostavu nove virtualne demokracije koja bi mogla biti rasprostranjena širom svijeta i tako konačno ispuniti snove filozofa i aktivista o kozmopolitskoj svjetskoj zajednici. Ako njen cilj shvatimo u prosvjetiteljskim okvirima $»$ kao krilo u kojem bi sve ljudske obdarenosti bile razvijene«, onda nam za nju zbilja nije nužna demokracija dobrohotni apsolutizam sasvim bi dostajao za ispunjenje ove svrhe. No ako i jest političkom kozmopolitizmu cilj uspostava neke vrste reda, nekog oblika mirovnog globalnog poretka koji bi omogućio razvoj i napredak ljudske rase, on sigurno nije i jedini. Tek kada bude omogućena svakom pojedincu pravedna prilika da na neki način sudjeluje u stvaranju zajedničke budućnosti, mogli bismo reći da je kozmopolitizam ispunio svoj cilj.

32

D. Held, Modeli demokracije, str. 283-284.

33

David Held, Cosmopolitanism - Ideals and Realities, Polity Press, Cambridge 2010.

34

Bhikhu Parekh, Nova politika identiteta - politička načela za međuovisni svijet, Politička kultura, Zagreb 2008.
35

Nacrt ove deklaracije još uvijek se može naći na internetskim stranicama. Vidi: http://www. interactioncouncil.org/universal-declarationhuman-responsibilities (pristupljeno 18. veljače 2016.). 


\title{
Marin Beroš
}

\section{Cosmopolitics as a Precondition for Global Justice}

\begin{abstract}
Lives that we are going to lead are not determined only by our bodies, they are also determined by the surroundings in which these bodies reside. The fact that the birth of a person of the same physical and mental abilities in different regions of the Earth leads to a completely different life opportunities should deeply concern us. While the sheer physicality cannot and should not be equalized to achieve fairness in opportunities that individuals have in society, relations within and among political communities could and should be changed if we want a fairer world. Cosmopolitics as a branch of political philosophy, through intertwining the ideas of cosmopolitanism and democracy, deals with the considerations of possibility and probability of creating the global political system that is at the same time just and efficient. This article will provide an overview of basic problems related to the establishment of cosmopolitan democracy, and finally, it will consider some of the concrete proposals for its establishment by the theorists such as David Held and Daniele Archibugi.
\end{abstract}

\section{Key words}

cosmopolitics, cosmopolitanism, global justice, global governance, cosmopolitan democracy 